\title{
Penerapan Menejemen Risiko Pada Pengelolaan Koperasi Pegawai Republik Indonesia (KPRI)
}

\author{
Yusuf Wibisono \\ STIE Widya Gama Lumajang \\ Liyundira90@gmail.com
}

https://doi.org/ 10.30741/adv.v3i2.511

\section{N F O A R T I K E L}

Tanggal masuk :

15 November 2019

Tanggal Revisi :

13 Desember 2019

Tanggal Diterima :

31 Desember 2019

\section{A B S T R A K}

Penelitian ini bertujuan untuk meneliti tentang perkembangan pengelolaan Koperasi Pegawai Republik Indonesia (KPRI) di Kabupaten Lumajang. Dimana sebagaian koperasi dapat berjalan dengan baik dan berhasil meraih prestasi yang dapat dibanggakan, sebagaian yang lain kurang dapat berkembang dengan baik, sebagian bermasalah, bahkan ada beberapa KPRI yang sudah tidak aktif lagi. Penelitian ini merupakan penelitian diskriptif kualitatif. Penelitian ini memberi gambaran secara sistematis tentang pengelolaan KPRI di Kabupaten Lumajang sebagaimana adanya. Dari beberapa KPRI di Kabupaten Lumajang terdapat KPRI-KPRI yang dapat menjalankan peran dan fungsinya secara nyata dalam mensejahterakan anggotanya. Tetapi ada beberapa KPRI yang tidak sehat dan akhirnya tidak dapat beraktifitas lagi. Dari 57 KPRI yang masih beraktifitas sebanyak 46 KPRI, sisanya yang sudah tidak beraktifitas sebanyak 11 KPRI. Faktor penyebab utama adalah karena tidak mampu mengatasi terjadinya risiko dalam berusaha. Maka, para pengelola dituntut mampu menerapkan manajemen risiko dalam menjalankan koperasi, dengan jalan memperkecil risiko, mengalihkan risiko, mengontrol risiko dan pendanaan risiko.

Kata Kunci : Pengelolaan KPRI, Peran Dan Fungsi Koperasi, Risiko Bisnis

\begin{abstract}
A B S T R A C T
This study aims to examine the development of the management of the Employee Cooperatives of the Republic of Indonesia (KPRI) in Lumajang Regency. Where some cooperatives can run well and achieve achievements that can be proud of, some others are less well developed, some have problems, some KPRI are no longer active. This study uses a qualitative descriptive approach, the research method uses interview methods and documentation. Also supported by a literature review that is relevant to the subject matter. This study provides a systematic overview of the management of KPRI in Lumajang Regency as it is. From several KPRI in Lumajang Regency, there are KPRI-KPRI that can carry out their roles and functions significantly in the welfare of their members. But there are some KPRI that are not healthy and finally can not work anymore. Of the 57 KPRI who are still active as many as 46 KPRI, the remaining 11 are not active. The main contributing factor is being unable to overcome the risk of trying. Thus, managers are required to be able to implement risk management in running cooperatives, by minimizing risk, transferring risk, controlling risk and risk funding.
\end{abstract}


Keywords: KPRI Management, Role and Function of Cooperatives, Business Risk

\section{PENDAHULUAN}

Pemerintah membuka peluang bagi koperasi untuk berkiprah dalam dunia usaha dan bisnis. Dalam Undang-Undang Nomor 25 Tahun 1992 tentang Perkoperasian dirumuskan tujuan utama koperasi, yaitu untuk memajukan kesejahteraan anggota pada khususnya dan masyarakat pada umumnya serta turut serta membangun tatanan perekonomian nasional dalam rangka mewujudkan masyarakat yang maju, adil dan makmur. Dari tujuan didirikannya koperasi tersebut dapat dinilai bahwa hadirnya koperasi yang bergerak dibidang usaha ekonomi sangat strategis dalam konsep pembangunan di Indonesia, terutama untuk mensejahterakan rakyatnya khususnya bagi para anggota koperasi. Menurut Herlambang dan Marwoto (2018:39), koperasi adalah organisasi ekonomi rakyat yang berwatak sosial beranggotakan orang atau badan hukum koperasi yang merupakan tata susunan ekonomi sebagai usaha bersama berdasarkan azas kekeluargaan. Menurut Undang-Undang Nomor 25 Tahun 1992 Koperasi adalah badan usaha yang beranggotakan orangseorang atau badan hukum koperasi, dengan melandaskan kegiataannya berdasarkan prinsip koperasi sekaligus sebagai gerakan ekonomi rakyat yang berdasar atas asas kekeluargaan.

Disamping itu, koperasi juga sebagai gerakan ekonomi rakyat, dan merupakan salah satu pilar ekonomi masyarakat. Melalui koperasi, para anggotanya dapat menjalankan usaha ekonomi bersama sesuai dengan kebutuhan anggota. Dan dari hasil usaha ekonomi itu dapat memperoleh keuntungan usaha yang dapat mensejahterakan para anggotanya. Meskipun gerak koperasi itu bukan semata-mata berorientasi pada profit. Dalam perjalanannya koperasi dapat berkembang sedemikian rupa. Ada banyak jenis koperasi yang berhasil didirikan. Menurut Herlambang dan Marwoto (2018:43), dilihat dari jenis usahanya, koperasi dibagi menjadi empat, yaitu koperasi konsumsi yaitu koperasi yang menyediakan keperluan sehari-hari bagi anggotanya, koperasi produksi yaitu koperasi yang memproduksi barang tertentu, koperasi jasa antara lain jasa simpan pinjam kepada anggotanya, Koperasi Serba Usaha (KSU) adalah jenis koperasi yang didalamnya terdapat berbagai macam bentuk usaha. Dilihat dari tingkat dan luas wilayahnya, ada dua jenis yaitu koperasi primer adalah koperasi yang beranggotakan orang-seorang dengan syarat minimal 20 orang, koperasi sekunder adalah koperasi yang didirikan oleh sebuah organisasi koperasi atau beranggotakan koperasi primer. Anggota koperasi sekunder adalah koperasi-koperasi yang memiliki kepentingan dan tujuan yang sama. Koperasi sekunder bisa didirikan oleh koperasi sejenis atau pun berbagai jenis atau tingkatan koperasi.

Jenis koperasi lainnya, dilihat berdasarkan status anggotanya ada lima jenis koperasi, koperasi pegawai negeri koperasi yang anggotanya terdiri dari para pegawai negeri disebut Koperasi Pegawai Republik Indonesia (KPRI) koperasi ini bertujuan untuk meningkatkan kesejahteraan ekonomi para anggotanya. Koperasi Pasar (Koppas), yaitu jenis koperasi yang anggotanya terdiri dari para pedagang pasar. Bentuk koperasinya dapat berupa koperasi simpan pinjam yang menyediakan pinjaman modal bagi para pedagang. Koperasi Unit Desa (KUD), yaitu koperasi yang anggotanya terdiri dari masyarakat pedesaan. Kegiatan koperasi ini biasanya melakukan kegiatan usaha di bidang ekonomi khususnya di bidang pertanian atau perikanan. Koperasi Sekolah. Anggota koperasi ini biasanya terdiri dari guru, siswa, dan karyawan pada sebuah sekolah. Koperasi pondok pesantren (Kopontren) adalah koperasi yang dikelola oleh pengurus pondok pesantren, santri, staf pengajar, dan karyawan. Relevan dengan pembahasan dalam penelitian ini, dari jenis-jenis koperasi diatas yang akan dipaparkan lebih lanjut adalah Koperasi Pegawai Negeri (KPRI) terutama koperasi primernya, yang bergerak dalam serba usaha, ada usaha pertokoan, simpan pinjam, jasa dan lain sebagainya. 
Idealnya, dalam usaha koperasi yang dijalankan, semua KPRI berusaha untuk memperoleh keuntungan. Dan tentu semua KPRI itu tidak menginginkan yang sebaliknya. Para anggota KPRI juga menginginkan KPRI-nya dapat berjalan dengan baik, terus berkembang maju dan memberi kesejahteraan kepada para anggotanya. Namun di lapangan, koperasi dihadapkan pada persaingan usaha. Koperasi bersaing untuk memperoleh modal, pelanggan, anggota dan sebagainya. Dalam persaingan tersebut koperasi dituntut keunggulannya dibanding dengan para pesaingnya. Bahkan jika perlu koperasi harus mempunyai keunggulan khusus yang tidak dimiliki oleh para pesaingnya. Harus disadari, bahwa dalam setiap usaha tidak lepas dari apa yang disebut dengan resiko usaha. Tegasnya, ada KPRI yang beruntung tapi juga ada yang rugi bahkan bangkrut.

Berdasar data dari Dinas Koperasi dan UKM Jawa Timur jumlah Koperasi sampai dengan tahun 2019 di Jawa Timur sebanyak 34.043. Sekiar 80 \% diantara koperasi itu masuk kategori koperasi yang produktif. Sisanya 9.626 unit atau 20 persen merupakan koperasi yang kurang produktif. Untuk perkembangan koperasi di Kabupaten Lumajang secara umum menunjukkan dinamika koperasi yang bagus, meski tidak semua koperasi selalu untung. Menurut Kepala Dinas Koperasi dan Usaha Mikro Kabupaten Lumajang Abdul Majid, jumlah koperasi di Kabupaten Lumajang tahun 2018 tercatat sebanyak 654 Koperasi. Dari 654 koperasi tersebut Koperasi aktif yang mengalami penurunan sebanyak 6\%, Koperasi tidak aktif mengalami kenaikan sebanyak $7 \%$, Koperasi yang melakukan RAT naik, tercatat sebanyak 378 Koperasi. Sedangkan, Koperasi yang telah mendapatkan Sertifikat Nomor Induk Koperasi (NIK) ada 413 Koperasi.

Khusus KPRI di Kabupaten Lumajang berdasarkan salah satu sumber informasi jumlahnya sebanyak 64 unit, yang aktif sampai sekarang sebanyak 46 unit dan yang sudah tidak aktif lagi sebanyak 18 unit. Agar koperasi dapat berkembang dengan baik, maka jalannya koperasi itu harus diikuti dengan pengembangan manajemen pengelolaan koperasi bagi pelaku-pelaku Koperasi itu sendiri, mengingat pertumbuhan kelembagaan yang tinggi tanpa diikuti dengan kompetensi dari para pelaku Koperasi memiliki resiko yang sangat tinggi bagi koperasi itu sendiri dimasa yang akan datang. Dalam konteks ini para pengurus KPRI perlu memahami tentang segala resiko yang dihadapinya dan mampu mengelola resiko tersebut dengan manajemen yang baik.

Berdasarkan sebagian sumber informasi, ada beberapa KPRI di Kabupaten Lumajang yang mengalami kemunduran, ada yang mengalami kerugian, bahkan ada KPRI yang berhenti beroperasi, diistilahkan dengan "mati suri". Itulah risiko yang muncul dalam perjalanan KPRI di Lumajang. Secara teoritis, risiko dalam dunia usaha ekonomi banyak ragam dan tipenya. Secara garis besar Fahmi (2015) dan Rustam (2017) menyebutkan dua tipe risiko, yaitu Risiko Murni (Pure Risk) dan Risiko Spekulatif (Speculative Risk). Menurut Sofyan ada dua risiko, yaitu risiko nonsistematis dan risiko sistimatis. Sedangkan Lam (2007) menyebut lima risiko, yaitu risiko pasar, risiko kredit, risiko operasional, risiko bisnis, dan risiko organisasional. Menurut Djohanputro (2008) risiko terdiri dari empat risiko, yaitu risiko keuangan, risiko operasional, risiko strategis dan risiko eksternalitas.

Risiko murni adalah risiko dimana ada kerugian, tetapi kemungkinan keuntungan tidak ada. Contohnya risiko kebakaran atau kecelakaan. Sedangkan risiko spekulatif adalah dimana ada kemungkinan terjadinya kerugian dan juga keuntungan. Pembelian saham, mungkin bisa untung tapi juga mungkin akan rugi. Risiko spekulatif ini juga disebut sebagai risiko bisnis. Seperti dijelaskan diatas, perkembangan koperasi secara umum di Kabupaten Lumajang menunjukkan dinamika yang positif, tetapi tidak menutup kemungkinan akan selalu ada risiko-risiko bisnis koperasi yang terjadi di kemudian hari. Untuk menghadapi risiko itu, para pengelola KPRI bisa mengambil beberapa langkah alternatif. Diantara alternatifnya, menurut Pertamihardja (2016:63), yaitu dengan menghindari risiko, mengurangi risiko, memindahkan risiko dan menerima risiko. Berdasarkan latar belakang masalah sebagaimana diuraikan diatas, maka penulis membuat penelitian analisa penerapan manajemen risiko pada pengelolaan Koperasi Pegawai Republik Indonesia (KPRI) Di Kabupaten Lumajang. Fokus masalah dalam penelitian ini tentang penerapan manajemen risiko dalam pengelolaan KPRI di Kabupaten Lumajang. 


\section{METODE PENELITIAN}

Penelitian ini merupakan penelitian deskriptif kualitatif, dimana peneliti bermaksud menganalisis data dengan cara mendeskripsikan atau mengambarkan data yang telah terkumpul sebagaimana adanya tanpa bermaksud membuat kesimpulan yang berlaku untuk umum atau generalisasi. Data Primer diperoleh dari survey langsung di PKP-RI Kabupaten Lumajang dan beberapa KPRI di Kabupaten Lumajang, ditunjang oleh data-data lain yang mendukung data primer tersebut.

\section{HASIL DAN PEMBAHASAN}

Koperasi Pegawai Negeri Republik Indonesia (KPRI) adalah koperasi yang anggotanya terdiri dari para pegawai negeri. Disebut Koperasi Pegawai Republik Indonesia (KPRI). Koperasi ini memiliki tujuan utama untuk meningkatkan kesejahteraan ekonomi anggotanya yang terdiri dari para Pegawai Negeri. Perkembangan KPRI di Kabupaten Lumajang ini berdasarkan data di PKPRI jumlahnya sebanyak 57 unit, yang aktif sampai sekarang sebanyak 46 unit dan yang sudah tidak aktif lagi sebanyak 11 unit. Untuk Koperasi Primer adalah koperasi yang beranggotakan orangseorang dengan syarat minimal 20 orang. KPRI primer di Lumajang tersebar se Kabupaten Lumajang. Jumlah KPRI primer yang masih eksis sebagaimana data diatas ada sebanyak 46 KPRI. Sedangkan Koperasi skunder adalah koperasi yang didirikan oleh sebuah organisasi koperasi atau beranggotakan koperasi primer. Di Lumajang koperasi skundernya adalah Pusat Koperasi Pegawai Republik Indonesia (PKP-RI)

Merujuk pernyataan Kepala Dinas Koperasi dan Usaha Mikro Kabupaten Lumajang Abdul Majid, secara umum ada peningkatan pertumbuhan Koperasi di Kabupaten Lumajang saat ini dalam berbagai aspek. Sedangkan menurut Ketua PKP-RI Kabupaten Lumajang, meskipun ada peningkatan pertumbuhan Koperasi, akan tetapi perkembangan KPRI sendiri di Kabupaten Lumajang belum dapat berjalan secara optimal. Bahkan sebagian KPRI mengalami nasib yang tidak menguntungkan, diantaranya ada KPRI yang berhenti beraktifitas. Diantara 57 KPRI ada KPRI yang berprestasi. Dalam waktu dua tahun terakhir, KPRI yang berprestasi dipegang oleh KPRI Pangudi Luhur RSU Lumajang (tahun 2018). Bupati Lumajang menyerahkan penghargaan koperasi dan usaha mikro terbaik tahun 2018 pada saat peringatan Hari jadi Koperasi Nasional ke 71 Kabupaten Lumajang. Salah satu penghargaan diberikan ke KPRI Pangudi Luhur.

Sedangkan pada tahun 2019 diraih oleh KPRI Guyub Rukun Rowokangkung. Penghargaan diserahkan pada peringatan Hari jadi Koperasi Nasional Kabupaten Lumajang di Rumah Makan Pondok Asri Sukodono Lumajang. Untuk KPRI Guyub Rukun Rowokangkung, KPRI ini bergerak pada layanan serba usaha, antara lain layanan usaha simpan pinjam, layanan usaha pertokoan dan layanan foto copy, layanan usaha jasa transportasi, dan layanan usaha-usaha lainnya.

Dibalik KPRI yang berprestasi, ada beberapa KPRI yang bermasalah, Gatot selanjutnya menjelaskan beberapa alasan atau faktor-faktor penyebab KPRI bermasalah, yaitu karena adanya kebijakan Pemerintah tentang restrukturisasi di Pemerintahan, seperti dihapusnya Departemen Penerangan, sehingga KPRI di Departemen yang bersangkutan berhenti dengan sendirinya. Dalam hal ini ada KPRI Anantakupa yang sudah tidak beraktifitas lagi, karena adanya kebijakan Pemerintah, yaitu penarikan urusan pemerintahan di Kabupaten/Kota ke Propinsi, sehingga KPRI di Kabupaten/Kota tidak dapat berjalan lagi. Dalam hal ini ada KPRI KOPDA dan KPRI Bondoyudo Lestari, karena KPRI tidak memenuhi syarat atau ketentuan batas anggota minimal 20 orang. Dalam hal ini ada KPRI Lestari yang anggotanya kurang dari 20 orang, karena terjadinya mis-manajemen pengelolaan koperasi. Dalam hal ini ada KPRI Praja Wibawa, KPRI Wira Bakti, KPRI Adil Makmur, KPRI Wahana Bakti, KPRI Rukun Sejahtera, dan lain-lain.

KPRI-KPRI yang bermasalah itu, yang telah berhenti beraktifitas dan tidak melaksanakan Rapat Anggota Tahunan (RAT) selama tiga tahun, sebenarnya bisa dibubarkan. Menurut Peraturan Menteri Koperasi Dan Usaha Kecil Dan Menengah Nomor 10/Per/M.KUKM/IX/2015 pasal 26 pembubaran Koperasi dapat dilakukan jika koperasi tersebut tidak melakukan Rapat Anggota Tahunan. Untuk beberapa KPRI di Kabupaten Lumajang yang telah berhenti beraktifitas dan tidak melaksanakan Rapat Anggota Tahunan (RAT) hingga saat ini belum dibubarkan. Jika diperhatikan 
perkembangan KPRI di Kabupaten Lumajang, dapat diketahui beberapa risiko yang muncul ke permukaan.

Relevan dengan pendapatnya Darmawi dan Godfrey, risiko yang dijumpai antara lain pertama, bersumber pada risiko sosial atau bersumber pada manusia (human), yaitu risiko yang sumbernya dari manusia seperti kesalahan melakukan prosedur, tidak kompeten, kelalaian, terjadinya penggelapan atau kecurangan oleh pengurus KPRI. Kedua, bersumber pada politik (political), yaitu risiko yang berasal dari kebijakan politik. Seperti kebijaksanaan pemerintah, perubahan peraturan, dan lain-lain. Salah satunya dihapusnya Departemen Penerangan dan penarikan urusan pemerintahan kabupaten/kota ke propinsi. Ketiga, bersumber pada pemasaran (marketing), yaitu risiko yang bersumber dari proses pemasaran. Terjadinya persaingan, kepuasan pelanggan, tren, dan lain-lain. Dalam hal ini usaha KPRI dihadapkan pada persaingan nyata dengan usaha pihak lain. Dibidang usaha pertokoan dihadapkan pada menjamurnya usaha ritel seperti Indomart, Alfamart dan lain-lain. Keempat, bersumber pada ekonomi (economic), yaitu risiko yang bersumber dari kebijakan ekonomi seperti bersumber pada kebijakan keuangan, kebijakan suku bunga, dan lain-lain. Dalam hal ini usaha simpan pinjam (USP) KPRI dihadapkan pada persaingan jasa (bunga) perbankan yang cenderung (trend) rendah atau turun. Kelima, bersumber pada keuangan (financial), yaitu risiko yang bersumber dari keuangan koperasi (perusahaan) seperti terjadinya kerugian, kebangkrutan, pengelolaan asuransi dan lain-lain. Dalam hal ini beberapa KPRI mengalami kerugian, baik dalam skala kecil maupun besar yang bisa menyebabkan kebangkrutan. Keenam, bersumber pada tindak kriminal (criminal), yaitu risiko karena adanya potensi tindak kriminal. misalnya terjadi kasus pencurian, korupsi dan lain sebagainya.

Risiko yang bersumber pada risiko fisik berupa kejadian alam (natural) seperti bencana longsor dan kebakaran sampai sekarang belum sampai terjadi. Dengan demikian, usaha yang dijalankan oleh KPRI di Kabupaten Lumajang tidak sepi dari berbagai risiko. Dan sebagian risiko itu benarbenar sudah terjadi. Dampak buruknya menjadikan beberapa KPRI berhenti beroperasi, beberapa KPRI lainnya terbelit dengan sejumlah kerugian, dan dibidang usaha simpan pinjam terjadi penurunan gairah dikalangan anggota, mereka beralih pada pinjaman Bank-Bank dengan suku bunga rendah. Terkait dengan kondisi tersebut, maka para pengelola koperasi perlu penguatan kembali dalam menerapkan manajemen risiko. Manajemen risiko itu sangat penting untuk dilakukan untuk mempersiapkan perusahaan dalam menghadapi kondisi tertentu yang menyebabkan kerugian bagi perusahaan. Manajemen risiko juga difungsikan untuk memetakan berbagai risiko yang dapat sewaktu-waktu terjadi.

Penting bagi para pengelola KPRI faham tentang Manajemen risiko itu. Selanjutnya, penting juga bagi para pengelola koperasi untuk dapat melakukan tindakan-tindakan yang tepat dalam dalam pengelolaan risiko tersebut, baik yang dilakukan sebelum risiko itu terjadi sebagai tindakan preventif maupun setelah risiko itu betul-betul terjadi sebagai tindakan kontrol dan penanggulangan risiko. Merujuk pada pendapatnya Fahmi (2015) dan Pertamihardja (2016) ada beberapa cara menghadapi dan mengelola risiko. Pertama, memperkecil risiko, dengan cara membatasi dan meminimalisir keputusan yang berrisiko. KPRI yang rata-rata bergerak dibidang layanan usaha simpan pinjam dapat memperkecil risiko pinjaman (risiko kredit) dengan membuat syarat adanya jaminan (agunan). Atau dengan membatasi jumlah pinjaman yang tidak melebihi jumlah simpanan anggota yang bersangkutan. Kedua, mengalihkan risiko, dengan cara mengalihkan risiko pada tempat lain, misalnya dengan cara mengasuransikan bisnis guna menghindari risiko yang mungkin terjadi. Beberapa KPRI sudah melakukan ini, yaitu dengan cara mengasuransikan layanan bisnisnya. Ada juga beberapa KPRI yang membuat aturan tentang adanya dana risiko yang dikelola sendiri. Ketiga, mengontrol risiko, dengan cara mengantisipasi timbulnya risiko sebelum risiko itu betul-betul terjadi, seperti mamasang alat pengamanan atau menugaskan penjaga keamanan pada tempat-tempat yang dianggap vital. Dalam hal ini secara umum sudah dijalankan oleh para pengelola KPRI di Kabupaten Lumajang. Keempat, pendanaan risiko, dengan cara menyiapkan dana cadangan (reserve). Sebagian KPRI sudah membuat program 
dana cadangan untuk mengantisipasi terjadinya risiko atau yang lebih popular dengan istilah dana risiko.

Dalam realitanya, ketika beberapa cara menghadapi dan mengelola risiko itu dihadapkan pada risiko usaha koperasi yang telah terjadi, sebagian KPRI mampu menghadapi dan mengelola risiko dengan baik. Sehingga KPRI dapat berkembang dengan maju dan berprestasi. KPRI Pangudi Luhur RSU Lumajang tahun 2018 dan KPRI Guyub Rukun Rowokangkung tahun 2019 serta beberapa KPRI lainnya. Sementara KPRI lainnya ketika menghadapi dan mengelola risiko itu tidak bisa berjalan dengan baik. Akibatnya, KPRI yang dikelolanya berhenti beraktifitas, seperti yang dialami KPRI Praja Wibawa, KPRI Wira Bakti, KPRI Wahana Bakti, KPRI Rukun Sejahtera dan lain-lain. Sedangkan KPRI-KPRI tertentu memang harus menerima kenyataan, yakni menerima risiko yang tidak dapat ditolak akibat terjadinya kebijakan pemerintah (kebijakan politik). Kejadian seperti itu dialami oleh beberapa KPRI, seperti KPRI KOPDA, KPRI Anantakupa dan KPRI Bondoyudo Lestari.

Memperkuat kinerja para pengelola KPRI, peran PKP-RI Kabupaten Lumajang sebagai koperasi skunder yang beranggotakan KPRI-KPRI se Kabupaten Lumajang sangat diperlukan. PKPRI berperan untuk membina KPRI-KPRI dan mengarahkannya dengan menerapkan manajemen perkoperasian yang baik, transparan dan akuntabel. PKP-RI juga mengajak kerjasama KPRI-KPRI dalam membangun usaha yang memiliki prospek kemajuan. Yang dilakukan oleh PKP-RI itu sangat membantu dalam membimbing pengurus KPRI yang sedang bermasalah. Paling tidak ikut membantu pengurus KPRI yang bermasalah itu menemukan titik masalahnya dan memberikan beberapa alternatif solusinya. Hasil akhirnya dikembalikan kepada KPRI yang bersangkutan. Peran Pemerintah juga sangan urgen. Pemerintah memiliki tugas penting dalam mendorong dan menggerakkan koperasi di Indonesia sehingga bisa berjalan dengan baik dan berkembang maju. Pemerintah dalam hal ini memberikan bimbingan, pengawasan, perlindungan, dan fasilitas terhadap koperasi. Setidaknya ada empat peran penting Pemerintah, yaitu peran secara aktif, distributif, stabilitatif, dan dinamisatif. Dengan peran aktif, seharusnya Pemerintah bersikap aktif, karena jika bersikap pasif maka secara tidak langsung akan menghambat pertumbuhan dan perkembangan koperasi.

Peran distributif pemerintah dapat berperan untuk mendistribusikan sumber daya, kesempatan dan hasil ekonomi secara adil dan wajar. Dengan peran stabilitatif, Pemerintah berperan memelihara stabilitas perekonomian dan memulihkannya jika dalam keadaan tidak seimbang. Dan dengan peran dinamisatif, Pemerintah berperan untuk mendinamisasi koperasi dalam berbagai program koperasi yang bermanfaat untuk mensejahterakan anggotanya. Kemudian pada sisi lain, Pemerintah mempunyai fungsi penting terhadap perkembangan koperasi. Fungsi penting Pemerintah terhadap koperasi meliputi 4 hal, yaitu fungsi legislatif, edukatif, moril dan finansiil. Pertama, fungsi legislatif. Pemerintah dalam hal ini mengeluarkan sejumlah produk UndangUndang dan Peraturan tentang koperasi yang dapat dijadikan dasar dan kendali bagi pertumbuhan dan perkembangan koperasi. Kedua, fungsi edukatif, dalam hal ini menyangkut bimbingan dan pengawasan. Bimbingan dimaksudkan agar koperasi dapat terus berkembang. Yaitu dengan memberikan penyuluhan-penyuluhan dan pemberian petunjuk tentang pengelolaan koperasi yang sehat dan berkualitas. Ketiga, fungsi moril, dalam hal ini Pemerintah memberi dorongan, memberi fasilitas serta keringanan, pemberian subsidi dan lain sebagainya. Keempat, fungsi finansiil, dalam segi ini tidak terbatas pada kredit-kredit finansial dengan syarat-syarat yang mudah, namun juga mengenai berbagai sarana dan prasarana yang dibutuhkan oleh koperasi.

Dalam Undang-Undang Nomor 25 Tahun 1992 disebutkan, bahwa Pemerintah bertugas menciptakan dan mengembangkan iklim dan kondisi yang mendorong pertumbuhan serta permasyarakatan Koperasi. Pemerintah juga memberikan bimbingan, kemudahan, dan perlindungan kepada Koperasi (pasal 60). Disamping itu pada pasal 61 dan 62 disebutkan beberapa tugas penting Pemerintah antara lain untuk a. memberikan kesempatan usaha seluasluasnya kepada Koperasi; b. meningkatkan dan memantapkan kemampuan Koperasi agar menjadi 
Koperasi yang sehat, tangguh, dan mandiri; c.mengupayakan tata hubungan usaha yang saling menguntungkan antara Koperasi dengan badan usaha lainnya. Membantu pengembangan jaringan usaha koperasi dan kerja sama yang saling menguntungkan antar koperasi, membudayakan koperasi dalam masyarakat, mendorong, mengembangkan, dan membantu pelaksanaan pendidikan, pelatihan, penyuluhan, dan penelitian perkoperasian, memberikan kemudahan untuk memperkokoh permodalan koperasi serta mengembangkan lembaga keuangan koperasi, memberikan bantuan konsultasi guna memecahkan permasalahan yang dihadapi oleh koperasi dengan tetap memperhatikan anggaran dasar dan prinsip koperasi.

Di Lumajang, Pemerintah sudah menjalankan tugasnya dengan baik untuk menciptakan dan menggerakkan koperasi serta mendorong pertumbuhan koperasi yang sehat dan maju. Hasilnya, seperti pernyataan Kepala Dinas Koperasi dan Usaha Mikro Kabupaten Lumajang Abdul Majid, secara umum ada peningkatan pertumbuhan Koperasi di Kabupaten Lumajang dalam berbagai aspek. Bagaimana dengan adanya beberapa KPRI yang bermasalah, apa langkah-langkah yang dilakukan Pemerintah ? Harus diakui bahwa ada sejumnlah KPRI di Kabupaten Lumajang yang sudah tidak aktif lagi dengan beberapa faktor penyebab yang berbeda-beda. Dan hal itu menjadi bagian dari salah satu risiko usaha koperasi. Tidak selamanya semua koperasi dapat berhasil dalam berusaha. Ada faktor internal dan eksternal yang membelit usaha-usaha koperasi, yang tidak dapat diselesaikan dengan baik. Tentang Pembubaran koperasi itu sudah diatur dalam Undang-Undang. Pembubaran koperasi dapat dilakukan atas kehendak anggota melalui Rapat Anggota, juga dapat dilakukan oleh pejabat koperasi setempat, apabila pejabat koperasi yang bersangkutan melihat adanya alasan-alasan kuat untuk membubarkan suatu koperasi. KPRI-KPRI yang masalahnya tidak dapat diatasi sampai tidak dapat melakukan Rapat Anggota Tahunan (RAT), Pemerintah dapat menjatuhkan sanksi seperti yang dijelaskan pada pasal 46 dan 47. Pembubaran Koperasi dapat dilakukan berdasarkan keputusan Rapat Anggota, atau keputusan Pemerintah.

Keputusan pembubaran oleh Pemerintah apabila terdapat bukti bahwa koperasi yang bersangkutan tidak memenuhi ketentuan Undang-undang ini, kegiatannya bertentangan dengan ketertiban umum dan/atau kesusilaan, kelangsungan hidupnya tidak dapat lagi diharapkan. Keputusan pembubaran koperasi oleh pemerintah dikeluarkan dalam waktu paling lambat 4 (empat) bulan terhitung sejak tanggal diterimanya surat pemberitahuan rencana pembubaran tersebut oleh Koperasi yang bersangkutan. Dalam jangka waktu paling lambat 2 (dua) bulan sejak tanggal penerimaan pemberitahuan, Koperasi yang bersangkutan berhak mengajukan keberatan. Keputusan Pemerintah mengenai diterima atau ditolaknya keberatan atas rencana pembubaran diberikan paling lambat 1 (satu) bulan sejak tanggal diterimanya penyataan keberatan tersebut. Sesuai dengan ketentuan Undang-Undang tersebut diatas, menurut Ketua PKP-RI Kabupaten Lumajang, ada beberapa KPRI di Kabupaten Lumajang sebenarnya sudah harus dibubarkan. Tetapi entah apa pertimbangannya, Pemerintah hingga saat ini tidak membubarkan KPRI tersebut. Tugas PKP-RI sendiri sebatas pada mengarahkan saja jalannya roda koperasi, untuk keputusan akhirnya ada ditangan anggota KPRI itu sendiri dan ada pada keputusan Pemerintah.

\section{KESIMPULAN}

Dari pembahasan penelitian dapat diambil beberapa kesimpulan sebagai berikut Perkembangan Koperasi di Kabupaten Lumajang secara umum ada peningkatan pertumbuhan Koperasi dalam berbagai aspek. Dan untuk perkembangan KPRI di Kabupaten Lumajang hingga tahun 2019 sebanyak 57 KPRI, yang masih beraktifitas sebanyak 46, sisanya 11 KPRI sudah tidak ada aktifitas. Untuk KPRI berprestasi tahun 2018 diraih KPRI Pangudi Luhur RSU Lumajang dan untuk tahun 2019 diraih KPRI Guyub Rukun Rowokangkung. Dalam menghadapi berbagai risiko para pengelola koperasi dapat mengelola risiko tersebut dengan beberapa cara antara lain sebagai berikut : a. memperkecil risiko, dengan membatasi dan meminimalisir keputusan yang berrisiko. b. mengalihkan risiko, dengan cara mengalihkan risiko pada tempat lain, misalnya dengan cara mengasuransikan bisnis guna menghindari risiko yang mungkin terjadi. c. mengontrol risiko, dengan cara mengantisipasi terhadap timbulnya risiko sebelum risiko itu betul-betul terjadi, seperti 
mamasang alat pengamanan atau menugaskan penjaga keamanan pada tempat-tempat yang dianggap vital. d. pendanaan risiko, dengan cara menyiapkan dana cadangan (reserve). Langkahlangkah yang dilakukan Pemerintah dalam menggerakkan koperasi sebagaimana diatur dalam Undang-Undang Nomor 25 Tahun 1992 adalah sebagai berikut a. pemerintah bertugas menciptakan dan mengembangkan iklim dan kondisi yang mendorong pertumbuhan koperasi, $b$. Pemerintah juga memberikan bimbingan, kemudahan, dan perlindungan kepada Koperasi, c. Pemerintah memberi kesempatan usaha yang seluas-luasnya kepada Koperasi, d. Pemerintah bertugas meningkatkan dan memantapkan kemampuan Koperasi agar menjadi Koperasi yang sehat, tangguh, dan mandiri, d. Pemerintah mengupayakan tata hubungan usaha yang saling menguntungkan antara Koperasi dengan badan usaha lainnya. Membantu pengembangan jaringan usaha Koperasi dan kerja sama yang saling menguntungkan antarkoperasi, e. Pemerimntah membudayakan Koperasi dalam masyarakat, f. Pemerintah turut mendorong, mengembangkan, dan membantu pelaksanaan pendidikan, pelatihan, penyuluhan, dan penelitian perkoperasian, $g$. Pemerintah turut memberikan kemudahan untuk memperkokoh permodalan Koperasi serta mengembangkan lembaga keuangan Koperasi, h. memberikan bantuan konsultasi guna memecahkan permasalahan yang dihadapi oleh Koperasi dengan tetap memperhatikan Anggaran Dasar dan prinsip Koperasi, i. Khusus bagi KPRI yang sudah tidak dapat beraktifitas lagi dan sudah tidak melakukan RAT, Pemerintah dapat menjatuhkan sanksi pembubaran koperasi sesuai prosedur yang ditentukan.

Relevan dengan hasil penelitian dan pembahasan, maka perlu disampaikan beberapa saran sebagai berikut 1. Kepada Pemerintah diharapkan dapat melaksanakan tugas-tugasnya dalam menggerakkan koperasi di Kabupaten Lumajang agar dapat berkembang lebih maju lagi. 2. Kepada PKP-RI dapat ikut serta secara aktif dalam mengarahkan pengelolaan KPRI di Kabupaten Lumajang dan membuka konsultasi secara luas kepada KPRI-KPRI sebagai anggotanya serta memberikan advokasi bagi KPRI yang menghadapi berbagai risiko dalam usahanya. 3. Kepada para pengelola KPRI hendaknya amanah dalam menjalankan KPRI, mau meningkatkan kualitas manajemen koperasi dan mampu menerapkan manajemen risiko dalam kegiatan koperasinya.

\section{DAFTAR PUSTAKA}

Darmawi, H. (2014). Manajemen Risiko. PT. Bumi Aksara, Jakarta

Fahmi, I. (2015). Manajemen Risiko, Teori, Kasus dan Solusi. ALFABETA, Bandung

Herlambang, S dan Bambang, H. M. (2018). Pengantar Ilmu Bisnis, Parama Publishing, Yogyakarta

Indrawan, R. (2013). Pengantar Koperasi Untuk Perguruan Tinggi, Arfino Raya, Bandung

Pertamihardja, B. (2016). Manajemen Risiko Pengembang Properti Perusahaan, Teknosain, Yogyakarta

Riyanto, R., Bambang. (2017). Manajemen Risiko, Prinsip, Penerapan dan Penelitian, Salemba Empat, Jakarta

Sofyan, I. (2005). Manajemen Risiko, Graha Ilmu, Yogyakarta

Sugiyono, 2008, Metode Penelitian Kuantitatif Kualitatif Dan R\&D, ALFABETA, Bandung

Sumarsono, Sonny, 2003, Manajemen Koperasi, Teori Dan Praktek, Graha Ilmu, Yogyakarta

Sunarto, 2006, Manajemen Koperasi, Penerbit AMUS, Yogyakarta

Widiyati, Ninik, 2012, Manajemen Koperasi, PT. RINEKA CIPTA, Jakarta

Undang-Undang Nomor 25 Tahun 1992 tentang Perkoperasian

Peraturan Menteri Koperasi Dan Usaha Kecil Dan Menengah Nomor 10/per/ M.KUKM/IX/2015

Tentang Kelembagaan Koperasi

https://jurnal.unej.ac.id/index.php/JPE/article/view/8567. Diakses tgl.11 September 2019

http://repository.unej.ac.id/handle/123456789/746. Diakses tgl.11 September 2019

https://jurnalmahasiswa.unesa.ac.id/index.php/jupe/article/view/9236. Diakses tgl.11 Sep- tember 2019

https://journal.unnes.ac.id/nju/index.php/jda/article/view/1951. Diakses tgl.11 September 2019 
https://docplayer.info/41996674-Analisis-rasio-likuiditas-dan-rentabilitas-sebagai-penilaiankinerja-keuangan-pada-kpri-setia-kawan-kecamatan-tekung-kabupaten-lumajang-tahunbuku.html. Diakses tgl.11 September 2019

https://informazone.com/jenis-jenis-koperasi/ Diakses tgl.10 September 2019

http://kominfo.jatimprov.go.id/read/umum/tahun-2019-koperasi-di-jatim-mencapai-34-ribu-unit. Diakses Tgl. 10 September 2019

http://infopublik.id/kategori/nusantara/325336/koperasi-wanita-lumajang-diharapkan-bisakembangkan-ekonomi-produktif. Diakses Tgl. 10 September 2019

http://www.memotimurlumajang.id/2018/07/apa-kabar-kpri-wira-bhakti.html. Diakses Tgl. 10 September 2019

http://www.memotimurlumajang.id/2018/02/kpri-wira-bhakti-mati-suri-dinas.html. Diakses Tgl. 10 September 2019

http://www.memotimurlumajang.id/2012/12/ratusan-juta-uang-koperasi-guru_12.html. Diakses Tgl. 10 September 2019

https://jatim.kemenag.go.id/berita/503114/kpri-budi-santoso-kemenag-lumajang-selenggarakan-rkdan-rapb--tahun-buku-2018. Diakses Tgl. 10 September 2019

https://www.maxmanroe.com/vid/umum/pengertian-risiko.html. Diakses Tgl. 10 September 2019 